\title{
Source Term Determination for Spills of Binary Liquid Solutions
}

by

A. Blanchard

Westinghouse Savannah River Company

Savannah River Site

Aiken, South Carolina 29808

D. Hadlock

Westinghouse Safety Management Solutions

SC USA

This paper was prepared in connection with work done under the above contract number with the U. S.

Department of Energy. By acceptance of this paper, the publisher and/or recipient acknowledges the U. S. Government's right to retain a nonexclusive, royalty-free license in and to any copyright covering this paper, along with the right to reproduce and to authorize others to reproduce all or part of the copyrighted paper. 


\section{DISCLAIMER}

This report was prepared as an account of work sponsored by an agency of the United States Government. Neither the United States Government nor any agency thereof, nor any of their employees, makes any warranty, express or implied, or assumes any legal liability or responsibility for the accuracy, completeness, or usefulness of any information, apparatus, product, or process disclosed, or represents that its use would not infringe privately owned rights. Reference herein to any specific commercial product, process, or service by trade name, trademark, manufacturer, or otherwise does not necessarily constitute or imply its endorsement, recommendation, or favoring by the United States Government or any agency thereof. The views and opinions of authors expressed herein do not necessarily state or reflect those of the United States Government or any agency thereof.

This report has been reproduced directly from the best available copy.

Available to DOE and DOE contractors from the Office of Scientific and Technical Information, P. O. Box 62, Oak Ridge, TN 37831; prices available from (423) 576-8401.

Available to the public from the National Technical Information Service, U. S. Department of Commerce, 5285 Port Royal Road, Springfield, VA 22161. 


\section{DISCLAIMER}

Portions of this document may be illegible electronic image products. Images are produced from the best available original document. 
WSRC-TR-96-0404

Revision 0

\section{SOURCE TERM DETERMINATION FOR SPILLS OF BINARY LIQUID SOLUTIONS (U)}

Dennis Hadlock

$1 / 6 / 97$

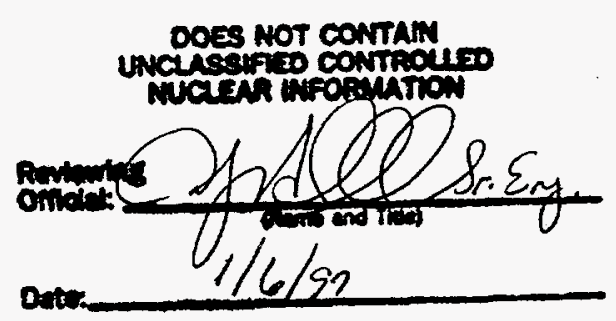

Westinghouse Savannah River Company Safety Engineering Department Aiken, SC 29808

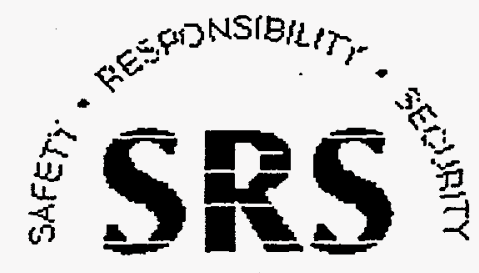


Keywords: Solutions

Chemical

Source Term

\section{AUTHOR/TECHNICAL REVIEW}

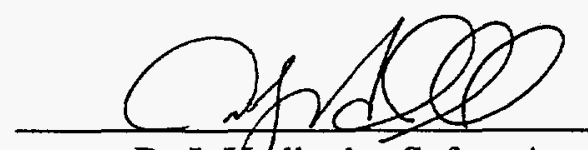

D. J. Ifadlock - Safety Analysis Engineering Section

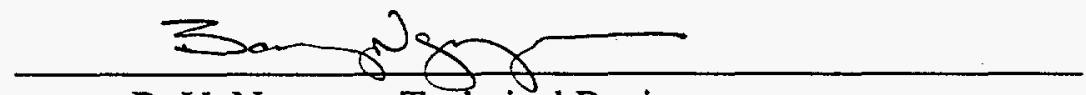

B. V. Nguyen - Technical Reviewer
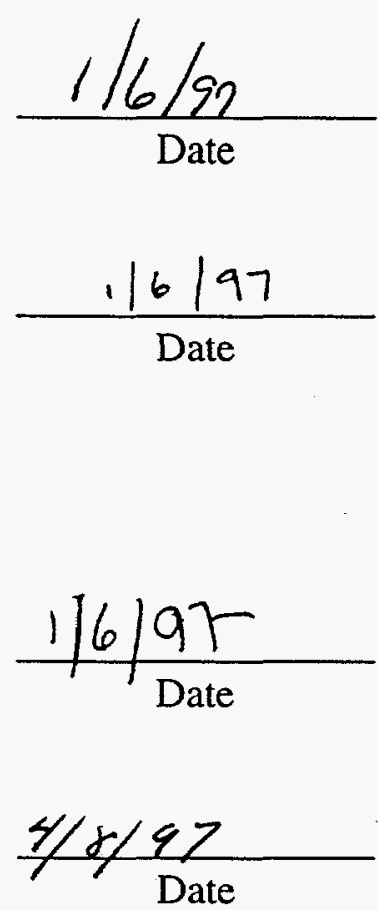

Date

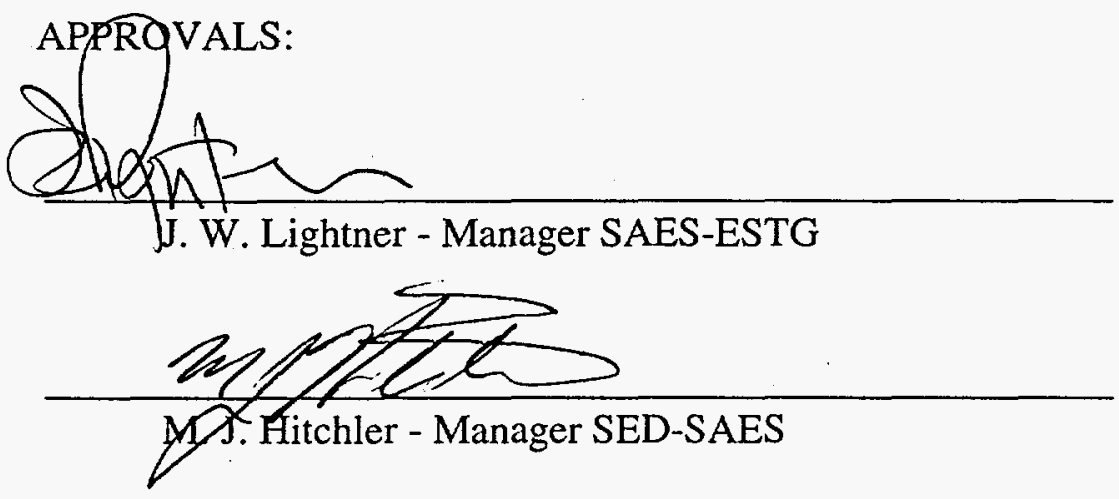




\section{SUMMARY}

Source term determination for spills of binary liquid solutions pose a unique dilemma as the partial vapor pressures of the constituents change as the spill evaporates. The change in partial pressures is more pronounced as the difference in the constituent vapor pressures increases. Past practices have been to conservatively analyze these solutions by either of the following two methods:

(1) Calculate the source term based on the partial pressure of the most limiting constituent (from a toxicological standpoint) when the partial pressure of that constituent will decrease as the spill evaporates.

(2) Calculate the theoretical mass transfer equilibrium concentration of the solution and use the partial pressure of the most limiting constituent (from a toxicological standpoint) at the equilibrium concentration when the partial pressure of that constituent will increase as the spill evaporates.

The drawback to the above practices are that they can greatly overestimate the source term when the partial pressure of the most limiting constituent decreases rapidly or increases slowly after the spill begins to evaporate. The methodology in this report takes advantage of the physical properties of the binary solution and the methodology used in calculating evaluation criteria for the solution of concern to provide a technical basis to remove some of this conservatism.

The methodology in this report results in the determination of an average vapor pressure over a predetermined time period of interest. The time period of interest is based on whether the most limiting constituent partial pressure increases or decreases over time. This average partial pressure is then used for determination of source terms for spills of the solution. 


\section{CONTENTS}

INTRODUCTION

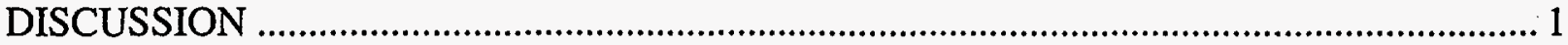

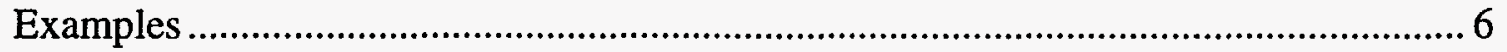

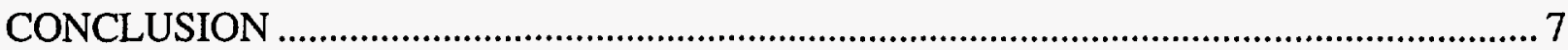

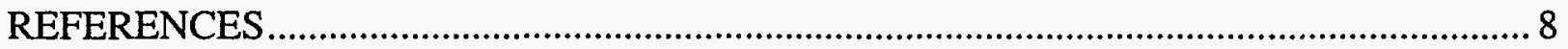

\section{TABLES}

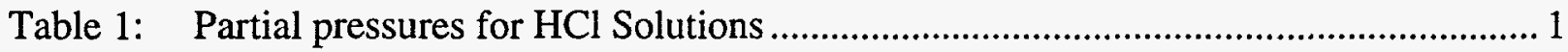

Table 2: Partial pressures for $\mathrm{HNO}_{3}$ Solutions................................................................... 2

Table 3: $\quad \mathrm{HCl}$ release rates - Kawamura and Mackay ............................................................. 4

Table 4: $\mathrm{HCl}$ release rates - Eckert-Drake ............................................................................. 5

\section{APPENDICES}

Appendix 1: EXCEL ${ }^{\top M}$ Spreadsheet of Source Term Model

Appendix 2: $\quad$ EXCEL $^{\mathrm{TM}}$ Spreadsheet of Eckert-Drake Source Term Model

Appendix 3: Pp Curves for $\mathrm{HCl}$ Solutions

Appendix 4: 36 Weight Percent $\mathrm{HCl}$ Analytical Dilution Steps for a $1000 \mathrm{lb}$ Spill Appendix 5: Pp Curves for $\mathrm{HNO}_{3}$ Solutions

Appendix 6: 50 Weight Percent $\mathrm{HNO}_{3}$ Analytical Concentration Steps for a $1000 \mathrm{lb}$ Spill 


\section{INTRODUCTION}

Binary liquid solutions pose a unique situation when determining the release rate (source term) from a spill of the solution. The vapor pressure of each of the two components, commonly referred to as the partial pressure ( $\mathrm{Pp})$, can vary widely over the range on concentration. This situation is encountered when calculating source terms for dilute acid mixtures. In this case one of the components, water, poses no toxicological hazard, while the other is the hazard of interest. Due to this difference in partial pressures, the solution can either dilute or concentrate over time. As the solution dilutes or concentrates, the $\mathrm{Pp}$ of the hazard will change accordingly. This change in $\mathrm{Pp}$ is directly related to the evaporation rate of the hazardous material in the solution.

A previous method (Ref. 1) of calculating the isothermal mass transfer equilibrium condition of a binary liquid mixture has been employed for safety analysis. A drawback to this method is that the answer is independent of the time it takes to reach the equilibrium mass transfer. Many times in safety analysis work, this length of time may be used as a mitigating feature for the accident being analyzed.

This report documents a method where the change in the Pp of each component is calculated over a period of time. The calculation yields an average $P p$ over the time period selected which allows the physical properties of the resulting average $\mathrm{Pp}$ to be used in the safety analysis.

\section{DISCUSSION}

Two solutions will be used for examples throughout this report. The two solutions are 36 weight percent hydrochloric acid $(\mathrm{HCl})$ and 50 weight percent nitric acid $\left(\mathrm{HNO}_{3}\right)$. These solutions were chosen as they represent the two possible endpoints of a solution over time, dilution and concentration. The partial pressures of $\mathrm{HCl}$ and water over aqueous solutions of $\mathrm{HCl} @ 30^{\circ} \mathrm{C}$ are (Ref. 2):

Table 1: Partial pressures for $\mathrm{HCl}$ Solutions

\begin{tabular}{|c|c|c|}
\hline $\begin{array}{c}\text { HCl } \\
\begin{array}{c}\text { Concentration } \\
\text { (wt\%) }\end{array}\end{array}$ & $\begin{array}{c}\text { Pp H2O } \\
\text { (mmHg) }\end{array}$ & $\begin{array}{c}\text { Pp HCl } \\
(\mathbf{m m H g})\end{array}$ \\
\hline 36 & 6.08 & 188.0 \\
\hline 34 & 7.32 & 92.0 \\
\hline 32 & 8.70 & 44.5 \\
\hline 30 & 10.20 & 21.0 \\
\hline 28 & 11.80 & 9.9 \\
\hline
\end{tabular}

As the $\mathrm{Pp}$ of the $\mathrm{HCl}$ is much greater than the $\mathrm{Pp}$ of water, the solution would be expected to dilute over time (in the case of $\mathrm{HCl}$, the large disparity between the two component Pvps would cause a relatively fast dilution over the first few minutes) until some equilibrium is reached. The use of the Pp at 36 weight \% for source term determination would result in an overestimation over a relatively long duration. 
The partial pressures of $\mathrm{HNO}_{3}$ and water over aqueous solutions of $\mathrm{HNO}_{3} @ 30^{\circ} \mathrm{C}$ are (Ref. 2):

Table 2: Partial pressures for $\mathrm{HNO}_{3}$ Solutions

\begin{tabular}{|c|c|c|}
\hline $\begin{array}{c}\mathrm{HNO}_{3} \\
\text { Concentration } \\
(w \mathrm{wt} \%)\end{array}$ & $\begin{array}{l}\text { Pp H2O } \\
(\mathrm{mmHg})\end{array}$ & $\begin{array}{r}\mathrm{Pp} \mathrm{HNO}_{3} \\
(\mathrm{mmHg})\end{array}$ \\
\hline 50 & 14.4 & 0.56 \\
\hline 55 & 12.2 & 0.93 \\
\hline 60 & 10.3 & 1.66 \\
\hline 65 & 8.8 & 3.17 \\
\hline 70 & 7.4 & 5.50 \\
\hline
\end{tabular}

As the $\mathrm{Pp}$ of $\mathrm{HNO}_{3}$ is much smaller than the $\mathrm{Pp}$ of water, the solution would be expected to concentrate over time until some equilibrium is reached. The use of the Pp at 50 weight $\%$ for source term determination could result in an underestimation for a relatively long duration.

In order to calculate the change in the solution, and thus the change in Pp, over time, it is necessary to choose a model for calculating source terms. For the purposes of this report, a manual model that could easily be adapted to an EXCEL ${ }^{\mathrm{TM}}$ spreadsheet was selected (Ref. 3). This model is commonly referred to as the Kawamura and Mackay Model. The formula used are as follows:

$$
S T=(A)\left(K_{M}\right)\left(\frac{M_{w} P_{v}}{R T}\right)
$$

where: $S T=$ source term $\left(\mathrm{kg}-\mathrm{sec}^{-1}\right)$

$$
\begin{aligned}
& A=\text { area of the evaporating puddle }\left(\mathrm{m}^{2}\right) \\
& K_{M}=\text { mass transfer coefficient }\left(\mathrm{m}-\mathrm{sec}^{-1}\right) \\
& M_{W}=\text { molecular weight of substance }\left(\mathrm{kg}^{-1} \mathrm{kmol}^{-1}\right) \\
& P_{v}=\text { vapor pressure }(\mathrm{Pa}) \\
& R=\text { universal gas constant }\left(8314 \mathrm{~J}-\mathrm{kmol}^{-1}-\mathrm{K}^{-1}\right) \\
& T=\text { ambient temperature }(\mathrm{K})
\end{aligned}
$$

The mass transfer coefficient, $K_{M}$, is calculated by:

$$
K M=0.0048\left(U^{7 / 9}\right)\left(z^{-1 / 9}\right)\left(S_{c}^{-2 / 3}\right)
$$

where: $U=$ wind speed at a height of $10 \mathrm{~m}\left(\mathrm{~m}-\mathrm{sec}^{-1}\right)$

$Z=$ pool diameter in the wind direction $(\mathrm{m})$

$S_{c}=$ the laminar Schmidt number 
The laminar Schmidt number is calculated by:

$$
S c=v / D_{M}
$$

$$
\text { where: } \begin{aligned}
v & =\text { the kinematic viscosity of the air }\left(\mathrm{m}^{2} \sec ^{-1}\right) \\
\mathrm{D}_{\mathrm{M}} & =\text { The molecular diffusivity of } \mathrm{HCl} \text { in air }\left(\mathrm{m}^{2} \mathrm{sec}^{-1}\right)
\end{aligned}
$$

The molecular diffusivity of $\mathrm{HCl}$ is approximated by:

$$
D_{M}=D_{H 2 O} \sqrt{\frac{M w_{H 2 O}}{M w_{H C l}}}
$$

Appendix 1 shows the final spreadsheet setup for equations 1.0 through 4.0.

As stated previously, the concept is to determine the average $\mathrm{Pp}$ of the solution over a predetermined time period and then use this Pp to obtain input data for the accident analysis. The general methodology to calculate the average $\mathrm{Pp}$ is as follows:

1. The partial pressures of the solute and solvent are graphed in order to interpolate values between those given from a standard reference (as in Tables 1 and 2 of this report).

2. Using the source term spreadsheet (Appendix 1), calculate the release rate of the solution components for a predetermined spill volume.

3. The amount of each component evaporated for the time duration of choice is determined and subtracted from the original amounts of each component.

4. The new weight percent of the solution is calculated for the remaining solution, the proper $\mathrm{Pp}$ for each component is obtained from step 1 above and then input for the next time period. The change in density of the solution should be considered but can normally be ignored.

5. The process is continued through the time period of interest for the release.

6. The total amount of the hazardous component (e.g., $\mathrm{HCl}$ or $\mathrm{HNO}_{3}$ ) released over the time period is calculated and divided by the time period to obtain the average release rate.

7. The Pp input into Appendix 1 is iterated until the release rate in step 6 is achieved. This $P p$ input is the "average" Pp over the time period of interest. 
In the above methodology, there are three basic assumptions the analyst needs to decide upon prior to performing the analysis, they are (1) the predetermined spill volume, (2) analytic time period for each dilution/concentration step, and (3) the total time period of interest to calculate the average $\mathrm{Pp}$. These three assumptions are arrived at as follows:

\section{(1) Predetermined Spill Volume}

If only one accident is being analyzed, it is logical that the accident spill size would be used. However, if it is desired to calculate an average $P p$ that can be used for varying spill volumes more information is needed. Some source term models are more sensitive to the spill volume input than others (related to the complexity of the model). As an example, the model used in this report shows the following sensitivity (normalized to the release rate per square meter) for various spills of $\mathrm{HCl}$ at a $\mathrm{Pp}$ of $10225 \mathrm{~Pa}$ :

Table 3: $\mathrm{HCl}$ release rates - Kawamura and Mackay

\begin{tabular}{|c|c|}
\hline $\begin{array}{c}\text { Volume } \\
\text { (gal) }\end{array}$ & $\begin{array}{c}\text { Release Rate } \\
\left(\mathrm{g}-\mathbf{m i n}^{-1} \mathbf{~ m}^{-2} \text { ) }\right.\end{array}$ \\
\hline 100 & 37.1 \\
\hline 500 & 34.0 \\
\hline 1000 & 32.8 \\
\hline 2000 & 31.5 \\
\hline
\end{tabular}

Using the results in table 3 and depending on the range of accidents to be analyzed, selecting a predetermined spill size of 500 to 1000 gallons should be sufficient to cover a large range of spills.

For comparison, another model suitable for spreadsheet adaptation, the Eckert-Drake model (Ref. 4), was also looked at. The spreadsheet for this model is contained in Appendix 2. The formulas used within the Eckert Drake spreadsheet are as follows:

$$
m=h d A\left(\frac{M \Delta p}{R_{g} T}\right)
$$

where: $m=$ mass transfer rate (release rate)

$h_{d}=$ mass transfer coefficient

$A=$ surface area of pool $\left(\mathrm{m}^{2}\right)$

$\Delta p=$ difference between the liquid phase vapor pressure and the gas phase partial pressure

$R_{g}=$ gas law constant

$T=$ air temperature $(\mathrm{K})$ 
The variable $h_{d}$ above is calculated by:

$$
\begin{array}{rrr}
h d=0.644 \frac{D}{L} R e^{1 / 2} S c^{1 / 2} & \text { (laminar) } & \text { for } R e<500,000 \\
h d=\frac{D}{L}\left[0.037 R e^{0.8}-871\right] S c^{1 / 3} & \text { (mixed) } & \text { for } R e \geq 500,000
\end{array}
$$

where $D=$ diffusion coefficient of volatile component in air

$L=$ pool length parallel to direction of flow

$R e=$ Reynolds number

$S c=$ Schmidt number

The Reynolds and Schmidt numbers are defined as:

$$
R e=\frac{L u \rho}{\mu} \text { and } S c=\frac{\mu}{D \rho}
$$

where: $L=$ pool length parallel to direction of flow

$$
\begin{array}{lll}
u & = & \text { wind velocity }\left(\mathrm{m}-\sec ^{-1}\right) \\
\rho & = & \text { density of air } \\
\mu & = & \text { viscosity of air }
\end{array}
$$

Performing the same modeling as for Table 3, the results with the Eckert-Drake model are:

Table 4: $\mathrm{HCl}$ release rates - Eckert-Drake

\begin{tabular}{|c|c|}
\hline $\begin{array}{c}\text { Volume } \\
\text { (gal) }\end{array}$ & $\begin{array}{c}\text { Release Rate } \\
\text { (g-min }^{-1} \mathbf{~ m}^{-2} \text { ) }\end{array}$ \\
\hline 100 & 8.9 \\
\hline 500 & 13.3 \\
\hline 1000 & 14.2 \\
\hline 2000 & 14.6 \\
\hline
\end{tabular}

The Eckert-Drake model shows a greater sensitivity to pool size due to the input for the mass transfer coefficient changing from the 100 to the 500 gallon spill size (the Reynolds number transitions above the 500,000 trigger point between these two spill sizes). As such, greater care should be taken for selection of the pool size.

\section{(2) Analytic Time Period for Dilution/Concentration Step}

Selecting this time period is dependent on whether or not the solution of interest is diluting (more hazardous material evaporating) or concentrating (less hazardous material evaporating). As most analysis desire to show a level of conservatism it is important to select time periods that can 
support this desire. For a solution that is diluting, use of a relatively long time period would over emphasize the initial high Pp of the component of interest thus not showing a "conservative" analysis. For a solution that is concentrating, use of a long time period would overemphasize the high Pp of the non (or less) toxic component which would result in a more conservative (faster) concentration time. In all cases the smaller the time intervals, the better the analysis. Practical application of the methodology forces the analyst to choose the desired conservatism in the analysis and thus the actual time interval used.

As the methodology for finding the average $\mathrm{Pp}$ is an iterative process, it is possible to start with a small time period and then base any increase in the time period on the results of the first few analyses.

\section{(3) Total Time Period of Interest}

Again, selection of this time period will depend greatly on whether or not the solution of interest is diluting or concentrating. In the case of a diluting solution (e.g., 36 weight $\% \mathrm{HCl}$ ), the average $\mathrm{Pp}$ from the time of the spill to the desired endpoint will produce the highest results. At WSRC, most analyses for chemical source terms and dispersion are compared to the Emergency Response Planning Guideline (ERPG) or Temporary Emergency Exposure Limits (TEEL) value (Ref. 5). The averaging time for calculating the ERPG/TEEL is normally 15 minutes (Ref. 6). As such, a 15 minute time period for a diluting solution is a logical choice.

If a solution is concentrating (e.g., 50 weight $\% \mathrm{HNO}_{3}$ ), there are actually two time periods of interest. The first is the time period for the calculation of the Pp. Again using the logic from above, 15 minutes is the logical choice. The second time period is, within the accident scenarios being analyzed, the time period between the spill and when mitigative actions are taken. For example, if the assumption is that mitigative actions can be assured within 8 hours, the material would be concentrated for 8 hours with the time period of 7.75 to 8.00 hours post-spill being used to calculate the average $\mathrm{Pp}$ to be used in analyzing the scenario.

\section{Examples}

The first example is the dilution of concentrated $\mathrm{HCl}$ after a spill. The $\mathrm{HCl}$ is assumed to be at 36 weight percent at the time of the spill. The Kawamura and Mackay model is used for source term determination. The spill size to be analyzed is $1000 \mathrm{lbs}$ (101.63 gallons), the analytic time period is one minute and the period of analysis is fifteen minutes. The $\mathrm{Pp}$ of the $\mathrm{HCl}$ and $\mathrm{H} 2 \mathrm{O}$ were graphed using EXCEL ${ }^{\mathrm{TM}}$. The graph was used to manually determine the $\mathrm{Pp}$ of $\mathrm{HCl}$ and $\mathrm{H} 2 \mathrm{O}$ after each analytical step. The graphs are contained within Appendix 3. The results from the analysis of each time step is contained within Appendix 4.

From Appendix 4, the total amount of $\mathrm{HCl}$ released over the 15 minute period is calculated by subtracting the final $\mathrm{HCl}$ mass from the initial mass of $360 \mathrm{lb}$. This results in:

$360 \mathrm{lb}-288.7 \mathrm{lb}=71.3 \mathrm{lb}$ of $\mathrm{HCl}$ vaporized over the first 15 minutes 
The average source term is calculated by dividing by the time period of interest (15 minutes) and converting to grams as follows:

$71.3 \mathrm{lb} / 15 \mathrm{~min}(454 \mathrm{~g} / \mathrm{lb})=2158 \mathrm{~g} / \mathrm{min}$ release rate (source term).

An "average" $\mathrm{HCl}$ partial pressure is calculated for the first 15 minutes through iteration of the Kawamura and Mackay EXCEL ${ }^{\top M}$ spreadsheet to attain the average source term. An average source term of $2158 \mathrm{~g} / \mathrm{min}$ results in an average Pp of $76.7 \mathrm{mmHg}$ for 36 weight percent $\mathrm{HCl}$. This represents a reduction of greater than one-half of the original $\mathrm{Pp}(188 \mathrm{mmHg})$ that would be used in other methods (Ref. 3).

The next example is the concentration of a $1000 \mathrm{lb}$ ( 92.3 gallon) spill of 50 weight percent $\mathrm{HNO}_{3}$. In this scenario, no mitigation is assumed for the first eight hours after the spill. Therefore, the concentration is calculated for the first 8 hours prior to performing any average $\mathrm{Pp}$ calculations. Appendix 5 contains the Pp curves for solutions of HNO3. Appendix 6 contains the results from the analysis at each time step. The time step initially selected was 30 minutes (as this is a concentration calculation, longer time steps are quicker and more conservative). Based on the concentration over the first three hours (50.0\% to 50.3\%), the time step was increased to one hour for the remainder of the analysis. In this example, the weight percent concentration/ $\mathrm{Pp}$ of the HNO3 was increased from $50 \% / 0.56 \mathrm{mmHg}$ to $50.9 \% / 0.62 \mathrm{mmHg}$. As the trend of concentration show a very small slope, the calculation of a 15 minute average for post mitigation time is not necessary. In this case the $0.62 \mathrm{mmHg} P \mathrm{p}$ would suffice.

The results of this methodology for 50 weight $\%$ HNO3 shows a significant difference when compared to the methodology contained within reference 1 . Using reference 1 and thus ignoring the time factor to reach equilibrium, the 50 weight $\% \mathrm{HNO} 3$ is assumed to concentrate to 66.56 weight \% (ref. 7). The use of the Pp at 66.56 weight $\%$ for source term analysis equates to a Pp for $\mathrm{HNO}_{3}$ of $3.8 \mathrm{mmHg}$, a six fold increase.

\section{CONCLUSION}

The use of the methodology contained within this report will calculate an average Pp for a binary chemical mixture that is less restrictive than the use of the initial Pp for binary mixtures that are diluting or the use of the mass transfer equilibrium $\mathrm{Pp}$ when the time of interest is less than the time to reach equilibrium.

All of the methodology in the report was performed manually in order to show the various steps in sufficient detail. This methodology utilizes source term codes easily adaptable to spreadsheets. The Pp curves could easily be input into common software (e.g., CricketGraph ${ }^{\top M}$ ) to generate a function specific to the graph. As such, putting this methodology into simple code in order to facilitate quicker results should not be a difficult task. 


\section{REFERENCES}

1. Kalinich, D. A., Determination of Isothermal Mass Transfer Equilibrium Conditions of Binary Liquid Mixtures, M-CLC-S-00383, 8/16/94.

2. R. H Perry and D. W. Green, Perry's Chemical Engineers' Handbook, sixth edition, McGraw-Hill Book Company, New York, 1984.

3. Evans, M, Modeling Hydrochloric Acid Evaporation in ALOHA ${ }^{T M}$, HAZMAT 93-3, July, 1993.

4. Eckert, E. R. G. and R. M. Drake, Heat and Mass Transfer, McGraw Hill Book Co, 1959.

5. Craig, D. K., ERPGs and TEELs for Chemicals of Concern at SRS: Rev. 11 (October 31 , 1996), ECS-CAT-96-0095, November 14, 1996.

6. Craig, D. K., WSRC-MS-92-206, Toxic Chemical Hazard Classification and Risk Acceptance Guidelines for use in DOE Facilities (U), Rev. 2, November 16, 1994.

7. Kalinich, D. A., Nitric Acid-Water Isothermal Mass Transfer Equilibrium at $35^{\circ} \mathrm{C}$, M-CLCS-00384, Revision 0, 8/18/94. 
Appendix 1 - EXCEL ${ }^{\mathrm{TM}}$ Spreadsheet of Kawamura and Mackay Source Term Model

\begin{tabular}{|c|c|c|c|}
\hline & $\mathbf{A}$ & $\mathbf{B}$ & $\mathrm{C}$ \\
\hline 1 & Parameter & Value & Dimensions \\
\hline 2 & E (Evaporation Rate) & $=\mathrm{A} * \mathrm{Km} * \mathrm{MW} * \mathrm{Pv} /(\mathrm{Rg} * \mathrm{~T})$ & $\mathrm{kg} / \mathrm{s}$ \\
\hline 3 & MW (Molecular Weight) & 36.5 & $\mathrm{~kg} / \mathrm{kg}$-mole \\
\hline 4 & Pv (Vapor Pressure) & 10225 & $\mathrm{~Pa}$ \\
\hline 5 & $\operatorname{Rg}$ (Gas Law Constant) & 8314 & $\mathrm{~J} / \mathrm{kgmole}-\mathrm{K}$ \\
\hline 6 & Temperature & 30 & ${ }^{\circ} \mathrm{C}$ \\
\hline 7 & Volume of Spill & 6.1 & gal \\
\hline 8 & d (Depth of Pool) & 0.01 & $\mathrm{~m}$ \\
\hline 9 & A (Surface Area of Spill) & $=\mathrm{V} / \mathrm{Depth}$ & $m^{\wedge} 2$ \\
\hline 10 & Km (Mass Transfer Coeff) & $=0.0048^{*} \mathrm{U}^{\wedge}(7 / 9)^{*} \mathrm{Z}^{\wedge}(-1 / 9)^{*} \mathrm{Sc}^{\wedge}(-2 / 3)$ & $\mathrm{m} / \mathrm{s}$ \\
\hline 11 & Z (Pool Diameter in Wind Direction) & $=\mathrm{SQRT}(4 * \mathrm{~A} / \mathrm{PI}(0)$ & $\mathrm{m}$ \\
\hline 12 & Sc (Schmidt Number) & $=\mathrm{nu} / \mathrm{Dm}$ & \\
\hline 13 & $\mathrm{U}$ (wind velocity) & 1.7 & $\mathrm{~m} / \mathrm{s}$ \\
\hline 14 & nu (kinematic viscosity of air) & 0.000015 & $\mathrm{~m}^{\wedge} 2 / \mathrm{sec}$ \\
\hline 15 & mu (viscosity of air) & 0.000019 & $\mathrm{~kg} / \mathrm{m}-\mathrm{s}$ \\
\hline 16 & Dm (Molecular Diffusivity of Solute in Air) & $=$ D_H20*SQRT(MW_H20/MW) & $\mathrm{m}^{\wedge} 2 / \mathrm{sec}$ \\
\hline 17 & D_H20 (Molecular Diffusivity of Water) & 0.000024 & \\
\hline 18 & MW_H20 & 18 & $\mathrm{~kg} / \mathrm{kg}$-mole \\
\hline 19 & & & \\
\hline 20 & Conversions & & \\
\hline 21 & $\mathrm{~T}$ (Absolute) & $=\mathrm{B} 6+273.15$ & $\mathrm{~K}$ \\
\hline 22 & V (Volume) & $=\mathrm{B} 7 * 0.0037853$ & $\mathrm{~m}^{\wedge} 3$ \\
\hline 23 & Pv (Vapor Pressure) & $=\mathrm{Pv} / 133.32$ & $\mathrm{~mm} \mathrm{Hg}$ \\
\hline 24 & Evaporation Rate & $=E^{*} 1000 * 60$ & $\mathrm{~g} / \mathrm{min}$ \\
\hline
\end{tabular}




\section{Appendix 2 - EXCEL ${ }^{\text {TM }}$ Spreadsheet of Eckert-Drake Source Term Model}

\begin{tabular}{|c|c|c|c|}
\hline & $\mathbf{A}$ & $\mathbf{B}$ & $\mathrm{C}$ \\
\hline 1 & Parameter & Value & Dimensions \\
\hline 2 & mdot (Mass Transfer Rate) & $=h d^{*} A^{*} M W * d p /(R g * T)$ & $\mathrm{kg} / \mathrm{s}$ \\
\hline 3 & MW (Molecular Weight) & 37 & g/g-mole \\
\hline 4 & Vapor Pressure & 76.7 & $\mathrm{~mm} \mathrm{Hg}$ \\
\hline 5 & Rg (Gas Law Constant) & 0.0831451 & bar- $\mathrm{m}^{\wedge} 3 / \mathrm{kg}$-mole- ${ }^{\circ} \mathrm{K}$ \\
\hline 6 & Temperature & 30 & ${ }^{\circ} \mathrm{C}$ \\
\hline 7 & Volume of Spill & 1000 & gal \\
\hline 8 & d (Depth of Pool) & 0.01 & $\mathrm{~m}$ \\
\hline 9 & A (Surface Area of Spill) & $=V / D e p t h$ & $\mathrm{~m}^{\wedge} 2$ \\
\hline 10 & hd (Mass Transfer Coeff) & $=\mathrm{IF}(\mathrm{Re}<500000, \mathrm{~B} 20, \mathrm{~B} 21)$ & $\mathrm{m} / \mathrm{s}$ \\
\hline 11 & D (Diffusion Coeff) & 0.0000162 & $\mathrm{~m}^{\wedge} 2 / \mathrm{s}$ \\
\hline 12 & L (Pool Length) & $(4 * B 9 / 3.14159)^{\wedge}(1 / 2)$ & $\mathrm{m}$ \\
\hline 13 & $\operatorname{Re}$ (Reynolds Number) & $=\mathrm{L} * \mathrm{u} * \mathrm{rho} / \mathrm{mu}$ & \\
\hline 14 & Sc (Schmidt Number) & $=\mathrm{mu} /(\mathrm{D} * \mathrm{rho})$ & \\
\hline 15 & $\mathrm{u}$ (wind velocity) & 1 & $\mathrm{~m} / \mathrm{s}$ \\
\hline 16 & rho (density of air) & 1.2 & $\mathrm{~kg} / \mathrm{m}^{\wedge} 3$ \\
\hline 17 & mu (viscosity of air) & 0.000019 & $\mathrm{~kg} / \mathrm{m}-\mathrm{s}$ \\
\hline 18 & & & \\
\hline 19 & Conditional & & \\
\hline 20 & hd (if laminar) & $=0.644 *(\mathrm{D} / \mathrm{L}) * \mathrm{Re}^{\wedge} 0.5^{*} \mathrm{Sc}^{\wedge}(1 / 3)$ & \\
\hline 21 & hd (if mixed) & $=(\mathrm{D} / \mathrm{L})^{*}\left(0.037 * \mathrm{Re}^{\wedge} 0.8-871\right)^{*} \mathrm{Sc}^{\wedge}(1 / 3)$ & \\
\hline 22 & & & \\
\hline 23 & Conversions & & \\
\hline 24 & $\mathrm{~T}$ (Absolute) & $=\mathrm{B} 6+273.15$ & ${ }^{\circ} \mathrm{K}$ \\
\hline 25 & V (Volume) & $=\mathrm{B} 7 * 0.0037853$ & $\mathrm{~m}^{\wedge} 3$ \\
\hline 26 & dp 0 & $=\mathrm{B} 4 / 750.06$ & bar \\
\hline 27 & Evaporation Rate & $=E * 1000 * 60$ & $\mathrm{~g} / \mathrm{min}$ \\
\hline 28 & $2 \mathrm{hr}$ evaporation & $=(\mathrm{B} 27 * 120) / 1000$ & $\mathrm{~kg}$ \\
\hline
\end{tabular}


Appendix 3 - Pp Curves for $\mathrm{HCl}$ Solutions

\section{Pvp of $\mathrm{H} 2 \mathrm{O}$ over $\mathrm{HCl}$ Solution}

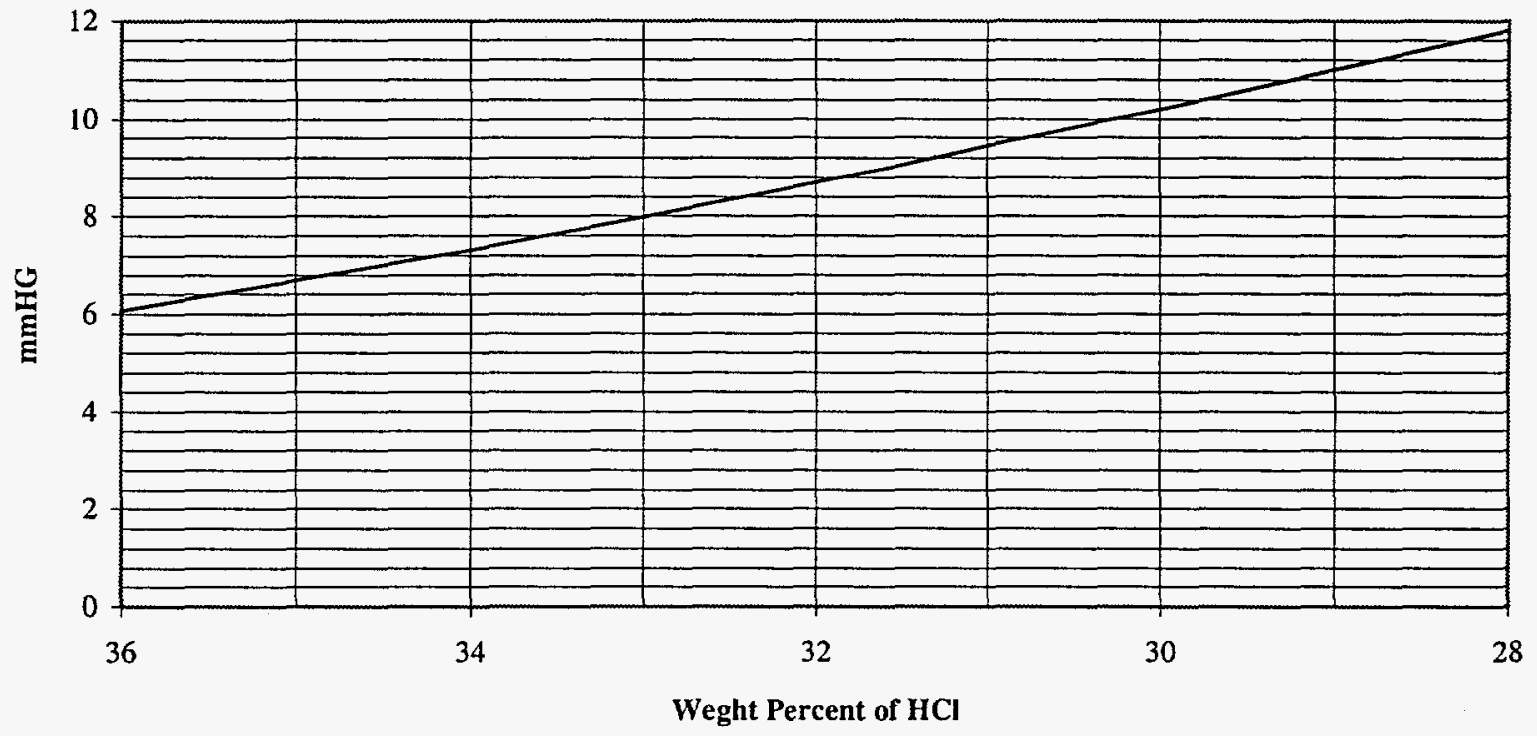

Pvp of $\mathrm{HCl}$ Over $\mathrm{HCl}$ Solution

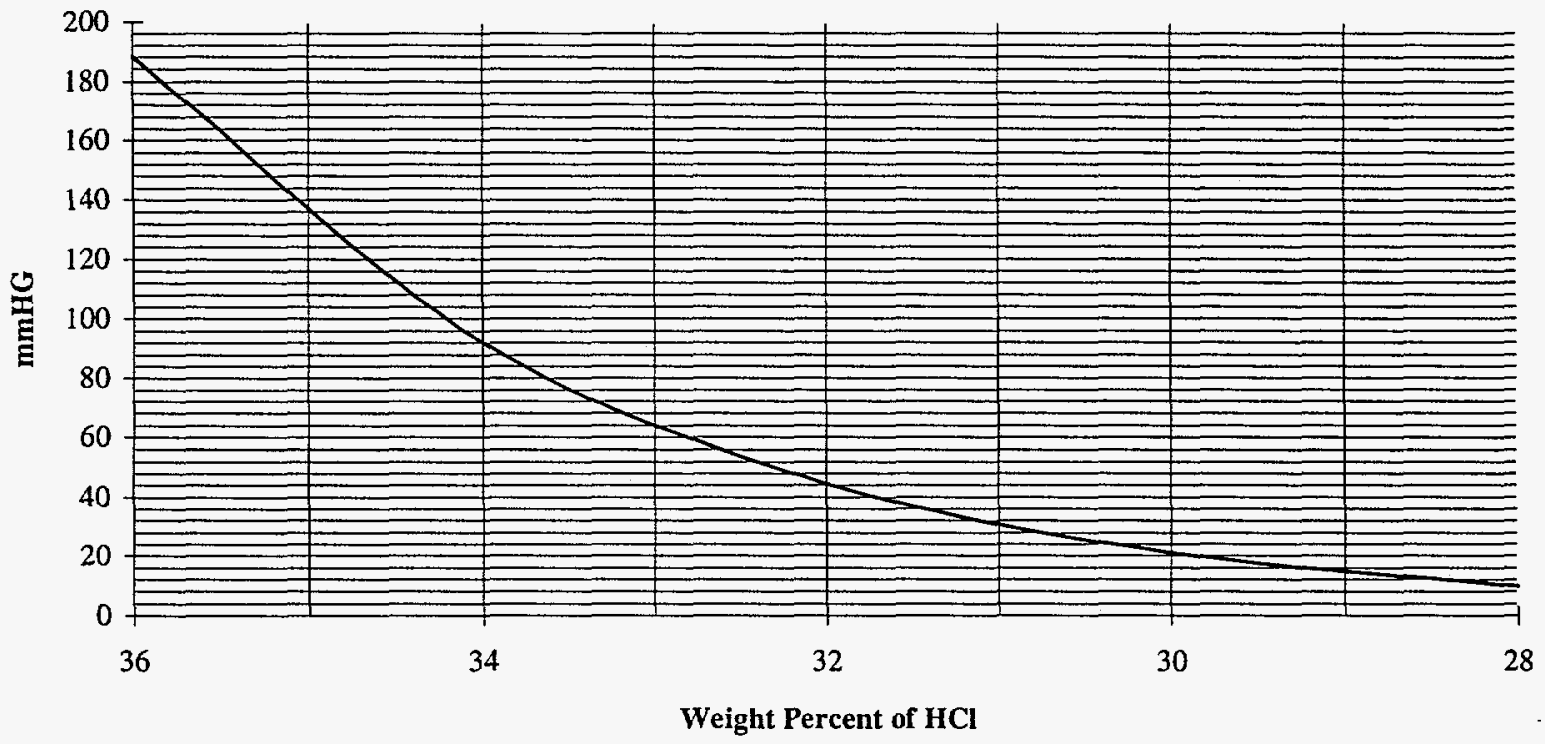


Appendix 4 - 36 Weight Percent $\mathrm{HCl}$ Analytical Dilution Steps for a $1000 \mathrm{lb}$ Spill

0-1 min.: $\quad \mathrm{Pp} \mathrm{HCl}=188 \mathrm{mmHg} \quad \mathrm{Pp} \mathrm{H}_{2} \mathrm{O}=6.08 \mathrm{mmHg}$

Evaporative rate $\mathrm{HCl}=5290 \mathrm{~g} / \mathrm{min}=11.65 \mathrm{lb}$ released

Evaporative rate $\mathrm{H}_{2} \mathrm{O}=107 \mathrm{~g} / \mathrm{min}=0.24 \mathrm{lb}$ released

$360 \mathrm{lb} \mathrm{HCl}-11.65 \mathrm{lb}=348.35$

$640 \mathrm{lb} \mathrm{H}_{2} \mathrm{O}-0.24 \mathrm{lb}=639.76$

new weight percent $=35.3$

1-2 min.: $\quad \mathrm{Pp} \mathrm{HCl}=152 \mathrm{mmHg} \quad \mathrm{Pp}_{2} \mathrm{O}=6.5 \mathrm{mmHg}$

Evaporative rate $\mathrm{HCl}=4277 \mathrm{~g} / \mathrm{min}=9.42 \mathrm{lb}$ released Evaporative rate $\mathrm{H}_{2} \mathrm{O}=114 \mathrm{~g} / \mathrm{min}=0.25 \mathrm{lb}$ released

$348.35 \mathrm{lb} \mathrm{HCl}-9.42 \mathrm{lb}=338.93$

$639.76 \mathrm{lb} \mathrm{H}_{2} \mathrm{O}-0.25 \mathrm{lb}=639.51$

new weight percent $=34.6$

2-3 min.: $\quad \mathrm{Pp} \mathrm{HCl}=116$ mmHg $\quad \mathrm{Pp} \mathrm{H}_{2} \mathrm{O}=6.9 \mathrm{mmHg}$

Evaporative rate $\mathrm{HCl}=3264 \mathrm{~g} / \mathrm{min}=7.20 \mathrm{lb}$ released Evaporative rate $\mathrm{H}_{2} \mathrm{O}=121 \mathrm{~g} / \mathrm{min}=0.27 \mathrm{lb}$ released

$338.93 \mathrm{lb} \mathrm{HCl}-7.20 \mathrm{lb}=331.73$

$639.51 \mathrm{lb} \mathrm{H}_{2} \mathrm{O}-0.27 \mathrm{lb}=639.24$

new weight percent $=34.2$

3-4 min.: $\quad \mathrm{Pp} \mathrm{HCl}=100 \mathrm{mmHg} \quad \mathrm{Pp} \mathrm{H}_{2} \mathrm{O}=7.2 \mathrm{mmHg}$

Evaporative rate $\mathrm{HCl}=2814 \mathrm{~g} / \mathrm{min}=6.20 \mathrm{lb}$ released Evaporative rate $\mathrm{H}_{2} \mathrm{O}=126 \mathrm{~g} / \mathrm{min}=0.28 \mathrm{lb}$ released

$331.73 \mathrm{lb} \mathrm{HCl}-6.20 \mathrm{lb}=325.53$

$639.24 \mathrm{lb} \mathrm{H}_{2} \mathrm{O}-0.28 \mathrm{lb}=638.97$

new weight percent $=33.8$ 
4-5 min.: $\quad \mathrm{Pp} \mathrm{HCl}=88 \mathrm{mmHg} \quad \mathrm{Pp}_{2} \mathrm{O}=7.5 \mathrm{mmHg}$

Evaporative rate $\mathrm{HCl}=2476 \mathrm{~g} / \mathrm{min}=5.45 \mathrm{lb}$ released Evaporative rate $\mathrm{H}_{2} \mathrm{O}=126 \mathrm{~g} / \mathrm{min}=0.29 \mathrm{lb}$ released

$325.53 \mathrm{lb} \mathrm{HCl}-5.45 \mathrm{lb}=320.08$

$638.97 \mathrm{lb} \mathrm{H}_{2} \mathrm{O}-0.29 \mathrm{lb}=638.68$

new weight percent $=33.4$

5-6 min.: $\quad \mathrm{Pp} \mathrm{HCl}=72 \mathrm{mmHg} \quad \mathrm{Pp} \mathrm{H}_{2} \mathrm{O}=7.7 \mathrm{mmHg}$

Evaporative rate $\mathrm{HCl}=2026 \mathrm{~g} / \mathrm{min}=4.46 \mathrm{lb}$ released Evaporative rate $\mathrm{H}_{2} \mathrm{O}=135 \mathrm{~g} / \mathrm{min}=0.30 \mathrm{lb}$ released

$320.08 \mathrm{lb} \mathrm{HCl}-5.45 \mathrm{lb}=315.62$

$638.68 \mathrm{lb} \mathrm{H} \mathrm{H}_{2} \mathrm{O}-0.30 \mathrm{lb}=638.38$

new weight percent $=33.1$

6-7 min.: $\quad \mathrm{Pp} \mathrm{HCl}=66 \mathrm{mmHg} \quad \mathrm{Pp} \mathrm{H}_{2} \mathrm{O}=7.9 \mathrm{mmHg}$

Evaporative rate $\mathrm{HCl}=1857 \mathrm{~g} / \mathrm{min}=4.10 \mathrm{lb}$ released Evaporative rate $\mathrm{H}_{2} \mathrm{O}=139 \mathrm{~g} / \mathrm{min}=0.31 \mathrm{lb}$ released

$315.62 \mathrm{lb} \mathrm{HCl}-4.10 \mathrm{lb}=311.52$

$638.38 \mathrm{lb} \mathrm{H}_{2} \mathrm{O}-0.31 \mathrm{lb}=638.07$

new weight percent $=32.8$

7-8 min.: $\quad \mathrm{Pp} \mathrm{HCl}=60 \mathrm{mmHg} \quad \mathrm{Pp} \mathrm{H}_{2} \mathrm{O}=8.1 \mathrm{mmHg}$

Evaporative rate $\mathrm{HCl}=1688 \mathrm{~g} / \mathrm{min}=3.72 \mathrm{lb}$ released Evaporative rate $\mathrm{H}_{2} \mathrm{O}=142 \mathrm{~g} / \mathrm{min}=0.31 \mathrm{lb}$ released

$311.52 \mathrm{lb} \mathrm{HCl}-3.72 \mathrm{lb}=307.80$

$638.07 \mathrm{lb} \mathrm{H}_{2} \mathrm{O}-0.31 \mathrm{lb}=637.76$

new weight percent $=32.6$ 
8-9 min.: $\quad \mathrm{Pp} \mathrm{HCl}=56 \mathrm{mmHg} \quad \mathrm{Pp} \mathrm{H}_{2} \mathrm{O}=8.3 \mathrm{mmHg}$

Evaporative rate $\mathrm{HCl}=1576 \mathrm{~g} / \mathrm{min}=3.47 \mathrm{lb}$ released Evaporative rate $\mathrm{H}_{2} \mathrm{O}=146 \mathrm{~g} / \mathrm{min}=0.32 \mathrm{lb}$ released

$307.80 \mathrm{lb} \mathrm{HCl}-3.47 \mathrm{lb}=304.33$

$637.76 \mathrm{lb} \mathrm{H}_{2} \mathrm{O}-0.32 \mathrm{lb}=637.44$

new weight percent $=32.3$

9-10 min.: $\quad \mathrm{Pp} \mathrm{HCl}=50 \mathrm{mmHg} \quad \mathrm{Pp}_{2} \mathrm{O}=8.5 \mathrm{mmHg}$

Evaporative rate $\mathrm{HCl}=1407 \mathrm{~g} / \mathrm{min}=3.10 \mathrm{lb}$ released Evaporative rate $\mathrm{H}_{2} \mathrm{O}=149 \mathrm{~g} / \mathrm{min}=0.33 \mathrm{lb}$ released

$304.33 \mathrm{lb} \mathrm{HCl}-3.10 \mathrm{lb}=301.23$

$637.44 \mathrm{lb} \mathrm{H}_{2} \mathrm{O}-0.33 \mathrm{lb}=637.11$

new weight percent $=32.1$

10-11 min.: $\quad \mathrm{Pp} \mathrm{HCl}=46 \mathrm{mmHg} \quad \mathrm{Pp} \mathrm{H}_{2} \mathrm{O}=8.6 \mathrm{mmHg}$

Evaporative rate $\mathrm{HCl}=1294 \mathrm{~g} / \mathrm{min}=2.85 \mathrm{lb}$ released Evaporative rate $\mathrm{H}_{2} \mathrm{O}=151 \mathrm{~g} / \mathrm{min}=0.33 \mathrm{lb}$ released

$301.23 \mathrm{lb} \mathrm{HCl}-2.85 \mathrm{lb}=298.38$

$637.11 \mathrm{lb} \mathrm{H}_{2} \mathrm{O}-0.33 \mathrm{lb}=636.78$

new weight percent $=31.9$

11-12 min.: $\quad \mathrm{Pp} \mathrm{HCl}=43 \mathrm{mmHg} \quad \mathrm{Pp} \mathrm{H}_{2} \mathrm{O}=8.8 \mathrm{mmHg}$

Evaporative rate $\mathrm{HCl}=1210 \mathrm{~g} / \mathrm{min}=2.67 \mathrm{lb}$ released Evaporative rate $\mathrm{H}_{2} \mathrm{O}=155 \mathrm{~g} / \mathrm{min}=0.34 \mathrm{lb}$ released

$298.38 \mathrm{lb} \mathrm{HCl}-2.67 \mathrm{lb}=295.71$

$636.78 \mathrm{lb} \mathrm{H}_{2} \mathrm{O}-0.34 \mathrm{lb}=636.44$

new weight percent $=31.7$ 
12-13 min.: $\quad \mathrm{Pp} \mathrm{HCl}=40 \mathrm{mmHg} \quad \mathrm{Pp} \mathrm{H}_{2} \mathrm{O}=8.9 \mathrm{mmHg}$

Evaporative rate $\mathrm{HCl}=1126 \mathrm{~g} / \mathrm{min}=2.48 \mathrm{lb}$ released Evaporative rate $\mathrm{H}_{2} \mathrm{O}=156 \mathrm{~g} / \mathrm{min}=0.34 \mathrm{lb}$ released

$295.71 \mathrm{lb} \mathrm{HCl}-2.67 \mathrm{lb}=293.23$

$636.44 \mathrm{lb} \mathrm{H}_{2} \mathrm{O}-0.34 \mathrm{lb}=636.10$

new weight percent $=31.6$

13-14 min.: $\quad \mathrm{Pp} \mathrm{HCl}=38 \mathrm{mmHg} \quad \mathrm{Pp} \mathrm{H}_{2} \mathrm{O}=9.0 \mathrm{mmHg}$

Evaporative rate $\mathrm{HCl}=1069 \mathrm{~g} / \mathrm{min}=2.36 \mathrm{lb}$ released Evaporative rate $\mathrm{H}_{2} \mathrm{O}=158 \mathrm{~g} / \mathrm{min}=0.35 \mathrm{lb}$ released

$293.23 \mathrm{lb} \mathrm{HCl}-2.36 \mathrm{lb}=290.87$

$636.10 \mathrm{lb} \mathrm{H}_{2} \mathrm{O}-0.35 \mathrm{lb}=635.75$

new weight percent $=31.4$

14-15 min.: $\quad \mathrm{Pp} \mathrm{HCl}=35 \mathrm{mmHg} \quad \mathrm{Pp} \mathrm{H}_{2} \mathrm{O}=9.1 \mathrm{mmHg}$

Evaporative rate $\mathrm{HCl}=985 \mathrm{~g} / \mathrm{min}=2.17 \mathrm{lb}$ released

Evaporative rate $\mathrm{H}_{2} \mathrm{O}=160 \mathrm{~g} / \mathrm{min}=0.35 \mathrm{lb}$ released

$290.87 \mathrm{lb} \mathrm{HCl}-2.17 \mathrm{lb}=288.70$

$635.75 \mathrm{lb} \mathrm{H}_{2} \mathrm{O}-0.35 \mathrm{lb}=635.40$

new weight percent $=31.2$ 


\section{Appendix 5 - Pp Curves for $\mathrm{HNO}_{3}$ Solutions}

\section{Pvp of H2O over HNO3 Solution}

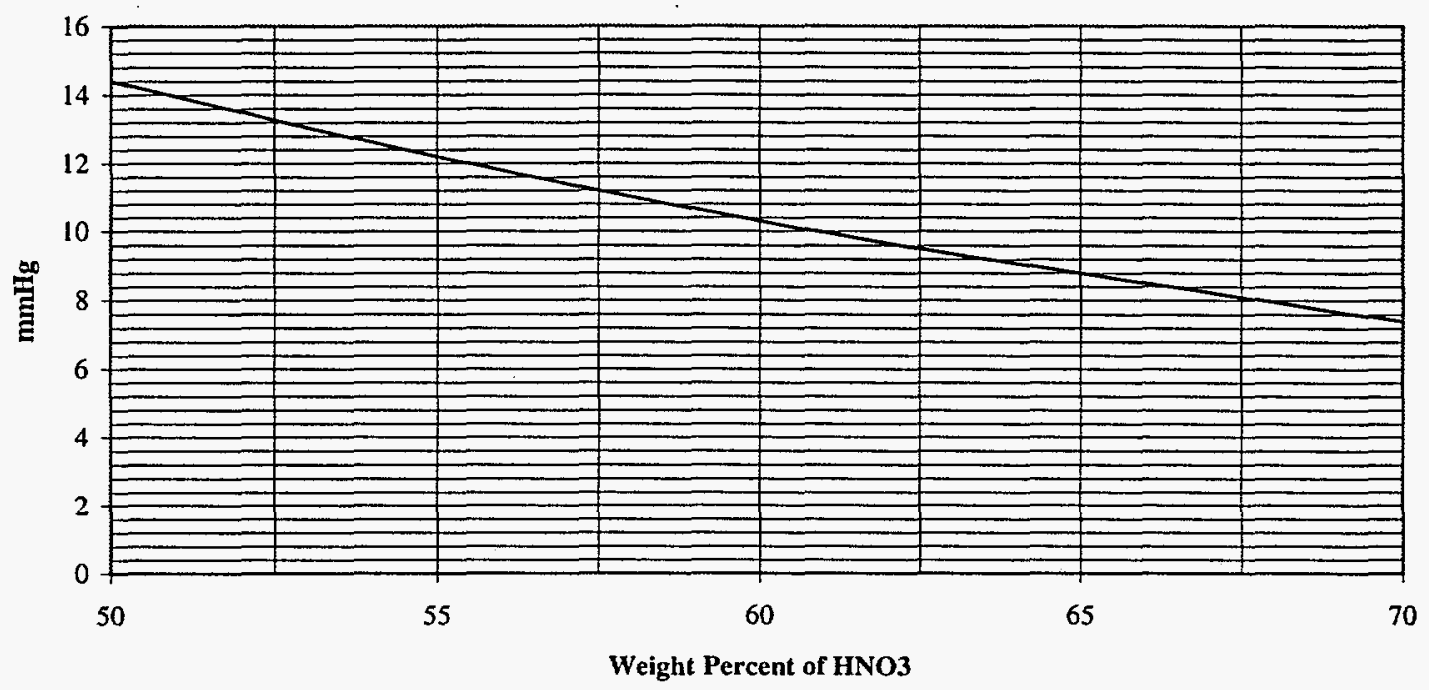

Pvp of HNO3 over HNO3 Solution

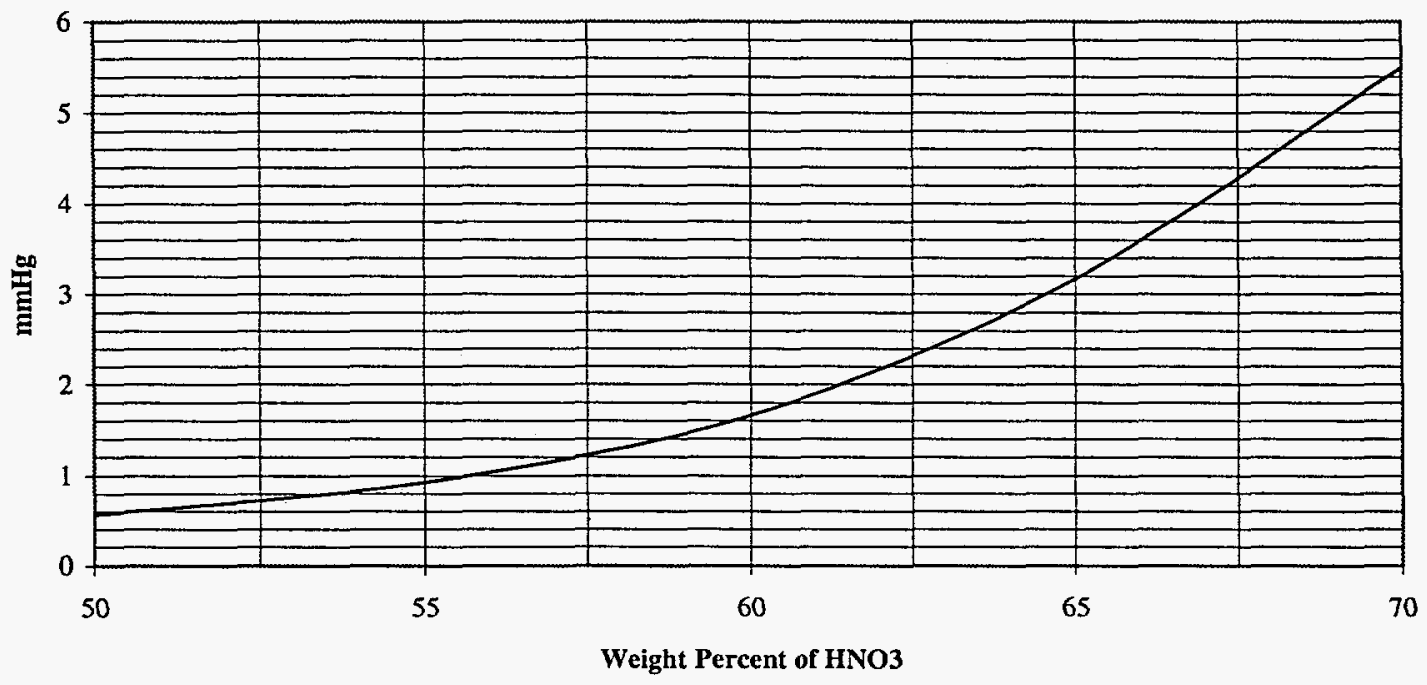


Appendix 6 - 50 Weight Percent $\mathrm{HNO}_{3}$ Analytical Concentration Steps for a $1000 \mathrm{lb}$ Spill

0-30 min.: $\quad \mathrm{Pp} \mathrm{HNO}_{3}=0.56 \mathrm{mmHg} \quad \mathrm{Pp} \mathrm{H}_{2} \mathrm{O}=14.4 \mathrm{mmHg}$

$30 \mathrm{~min}$ total Evaporation of $\mathrm{HNO}_{3}=0.11 \mathrm{lb}$ released

30 min total Evaporation of $\mathrm{H}_{2} \mathrm{O}=1.17 \mathrm{lb}$ released

$500 \mathrm{lb} \mathrm{HNO}_{3}-0.11 \mathrm{lb}=499.89$

$500 \mathrm{lb} \mathrm{H}_{2} \mathrm{O}-1.17 \mathrm{lb}=498.83$

new weight percent $=50.1$

30-60 min.: $\quad \mathrm{Pp} \mathrm{HNO}_{3}=0.56 \mathrm{mmHg} \quad \mathrm{Pp} \mathrm{H}_{2} \mathrm{O}=14.4 \mathrm{mmHg}$

$30 \mathrm{~min}$ total Evaporation of $\mathrm{HNO}_{3}=0.11 \mathrm{lb}$ released 30 min total Evaporation of $\mathrm{H}_{2} \mathrm{O}=1.17 \mathrm{lb}$ released

$499.89 \mathrm{lb} \mathrm{HNO}_{3}-0.11 \mathrm{lb}=499.78$

$498.83 \mathrm{lb} \mathrm{H}_{2} \mathrm{O}-1.17 \mathrm{lb}=497.66$

new weight percent $=50.1$

60-90 min.: $\quad$ Pp $\mathrm{HNO}_{3}=0.56 \mathrm{mmHg} \quad \mathrm{Pp} \mathrm{H}_{2} \mathrm{O}=14.4 \mathrm{mmHg}$

$30 \mathrm{~min}$ total Evaporation of $\mathrm{HNO}_{3}=0.11 \mathrm{lb}$ released 30 min total Evaporation of $\mathrm{H}_{2} \mathrm{O}=1.17 \mathrm{lb}$ released

$499.78 \mathrm{lb} \mathrm{HNO}_{3}-0.11 \mathrm{lb}=499.67$

$497.66 \mathrm{lb} \mathrm{H}_{2} \mathrm{O}-1.17 \mathrm{lb}=496.49$

new weight percent $=50.2$

90-120 min.: Pp $\mathrm{HNO}_{3}=0.57 \mathrm{mmHg} \quad \mathrm{Pp} \mathrm{H}_{2} \mathrm{O}=14.3 \mathrm{mmHg}$

$30 \mathrm{~min}$ total Evaporation of $\mathrm{HNO}_{3}=0.11 \mathrm{lb}$ released $30 \mathrm{~min}$ total Evaporation of $\mathrm{H}_{2} \mathrm{O}=1.17 \mathrm{lb}$ released

$499.67 \mathrm{lb} \mathrm{HNO}_{3}-0.11 \mathrm{lb}=499.56$

$496.49 \mathrm{lb} \mathrm{H}_{2} \mathrm{O}-1.17 \mathrm{lb}=495.32$

new weight percent $=50.2$ 
120-150 min.: Pp $\mathrm{HNO}_{3}=0.57 \mathrm{mmHg} \quad \mathrm{Pp} \mathrm{H}_{2} \mathrm{O}=14.3 \mathrm{mmHg}$

$30 \mathrm{~min}$ total Evaporation of $\mathrm{HNO}_{3}=0.11 \mathrm{lb}$ released $30 \mathrm{~min}$ total Evaporation of $\mathrm{H}_{2} \mathrm{O}=1.17 \mathrm{lb}$ released

$499.56 \mathrm{lb} \mathrm{HNO}_{3}-0.11 \mathrm{lb}=499.45$

$495.32 \mathrm{lb} \mathrm{H}_{2} \mathrm{O}-1.17 \mathrm{lb}=494.15$

new weight percent $=50.3$

150-180 min.: $\mathrm{Pp} \mathrm{HNO}_{3}=0.58 \mathrm{mmHg} \quad \mathrm{Pp} \mathrm{H}_{2} \mathrm{O}=14.3 \mathrm{mmHg}$

$30 \mathrm{~min}$ total Evaporation of $\mathrm{HNO}_{3}=0.11 \mathrm{lb}$ released 30 min total Evaporation of $\mathrm{H}_{2} \mathrm{O}=1.17 \mathrm{lb}$ released

$499.45 \mathrm{lb} \mathrm{HNO}_{3}-0.11 \mathrm{lb}=499.34$

$494.15 \mathrm{lb} \mathrm{H}_{2} \mathrm{O}-1.17 \mathrm{lb}=492.98$

new weight percent $=50.4$

180-240 min.: $\mathrm{Pp} \mathrm{HNO}_{3}=0.58 \mathrm{mmHg} \quad \mathrm{Pp} \mathrm{H}_{2} \mathrm{O}=14.3 \mathrm{mmHg}$

$30 \mathrm{~min}$ total Evaporation of $\mathrm{HNO}_{3}=0.22 \mathrm{lb}$ released 30 min total Evaporation of $\mathrm{H}_{2} \mathrm{O}=2.33 \mathrm{lb}$ released

$499.34 \mathrm{lb} \mathrm{HNO}_{3}-0.22 \mathrm{lb}=499.12$

$492.98 \mathrm{lb} \mathrm{H}_{2} \mathrm{O}-2.33 \mathrm{lb}=490.65$

new weight percent $=50.4$

240-300 min.: Pp $\mathrm{HNO}_{3}=0.58 \mathrm{mmHg} \quad \mathrm{Pp} \mathrm{H}_{2} \mathrm{O}=14.3 \mathrm{mmHg}$

$30 \mathrm{~min}$ total Evaporation of $\mathrm{HNO}_{3}=0.22 \mathrm{lb}$ released $30 \mathrm{~min}$ total Evaporation of $\mathrm{H}_{2} \mathrm{O}=2.33 \mathrm{lb}$ released

$499.12 \mathrm{lb} \mathrm{HNO}_{3}-0.22 \mathrm{lb}=498.90$

$490.65 \mathrm{lb} \mathrm{H}_{2} \mathrm{O}-2.33 \mathrm{lb}=488.32$

new weight percent $=50.5$ 
300-360 min.: $\mathrm{Pp} \mathrm{HNO}_{3}=0.59 \mathrm{mmHg} \quad \mathrm{Pp} \mathrm{H}_{2} \mathrm{O}=14.25 \mathrm{mmHg}$

$30 \mathrm{~min}$ total Evaporation of $\mathrm{HNO}_{3}=0.22 \mathrm{lb}$ released $30 \mathrm{~min}$ total Evaporation of $\mathrm{H}_{2} \mathrm{O}=2.32 \mathrm{lb}$ released

$498.90 \mathrm{lb} \mathrm{HNO}_{3}-0.22 \mathrm{lb}=498.68$

$488.32 \mathrm{lb} \mathrm{H}_{2} \mathrm{O}-2.32 \mathrm{lb}=486.00$

new weight percent $=50.6$

360-420 min.: Pp $\mathrm{HNO}_{3}=0.60 \mathrm{mmHg} \quad \mathrm{Pp} \mathrm{H}_{2} \mathrm{O}=14.2 \mathrm{mmHg}$

$30 \mathrm{~min}$ total Evaporation of $\mathrm{HNO}_{3}=0.23 \mathrm{lb}$ released $30 \mathrm{~min}$ total Evaporation of $\mathrm{H}_{2} \mathrm{O}=2.32 \mathrm{lb}$ released

$498.68 \mathrm{lb} \mathrm{HNO}_{3}-0.23 \mathrm{lb}=498.45$

$486.00 \mathrm{lb} \mathrm{H}_{2} \mathrm{O}-2.32 \mathrm{lb}=483.68$

new weight percent $=50.8$

420-480 min.: Pp $\mathrm{HNO}_{3}=0.62 \mathrm{mmHg} \quad \mathrm{Pp} \mathrm{H}_{2} \mathrm{O}=14.1 \mathrm{mmHg}$

$30 \mathrm{~min}$ total Evaporation of $\mathrm{HNO}_{3}=0.23 \mathrm{lb}$ released 30 min total Evaporation of $\mathrm{H}_{2} \mathrm{O}=2.30 \mathrm{lb}$ released

$498.45 \mathrm{lb} \mathrm{HNO}_{3}-0.23 \mathrm{lb}=498.22$

$483.68 \mathrm{lb} \mathrm{H}_{2} \mathrm{O}-2.30 \mathrm{lb}=481.38$

new weight percent $=50.9$ 